\title{
Guest Editor's Column
}

EACH of us, I suspect, has a well-stocked storehouse of MLA memories. Who can forget his or her first convention, first interview, first dues notice? How vivid the image remains of poring through the Program on a noisy flight to Chicago or of poring through the international bibliography in a quiet library. We remember hearing, or perhaps presenting, a controversial paper in a Hilton seminar room; encountering, in a crowded Hyatt elevator, the luminary whose new book has created such a stir; or renewing, in an understaffed lounge (with an overpriced drink), friendships with graduateschool classmates. These are memories that yet fresh memories beget.

My own most vivid recollections include the first of the twenty or so presidential addresses I have attended. The speaker was Marjorie Nicolson, and I confess that it didn't occur to me at the time to find it odd that she was only the second woman who had served as president during the long history of our association. I also remember, as clearly as if it were last week, tending bar at the executive director's party that same evening and being awed at the idea of pouring bourbon for the likes of President Nicolson, Frederick J. Hoffman, and George Winchester Stone, Jr. There were giants in those days.

It is appropriate, here in this centennial issue of $P M L A$, to pay homage to our enviable history and to our association's great figures, those who have contributed to a record of good and useful works. A hundred years of shared or similar memories give the MLA a kind of Jungian collective unconscious, making a bond among members of the profession, despite diffeiences in time and point of view. From the original forty founders on, the MLA has been blessed with an impressive membership, with names that echo down the corridors of academic history. At the same time, however, we should not, I am convinced, concentrate solely on the past to the exclusion of the present and future, should not permit the nostalgic impulse to blur our perspective on recent gains. There are luminaries in our midst today, too, and others will be in evidence tomorrow.

I do not want to undervalue nostalgia, especially in this celebratory context, but I would like to express the gentlest of reservations about the tendency to idealize the past and hence to overlook the efforts of the present. During my tenure as executive director I was sometimes told that the MLA was more collegial back in the halcyon Palmer House days, before things got "fragmented." A strategy I have developed when someone complains that our profession isn't what it used to be is to ask, "Was it ever?" Things have changed, of course they have, but more often than not the changes have been in the service of progress. Like many academic departments that have gradually evolved from gentlemen's clubs into intellectually stimulating groups that welcome all sorts of scholars (and points of view), the MLA, in recent decades, has become a society responsive to all members of our profession, regardless of gender, age, race, creed, rank, place of employment (or of nonemployment), or theoretical perspective. The Modern Language Association, in short, has grown up. It is possible, of course, that fifty years down the road-or perhaps sooner-members may look back on our current concerns, procedures, and efforts with wry disbelief, but that, after all, is the nature of progress.

In some respects, in fact, the association's relatively recent past seems to me to provide occasions not for celebration but for regret. Paul Lauter points out in his thoughtful essay that in 1958 women represented only $9.6 \%$ of the paper presenters or discussion leaders at the annual convention. And when I was a lad in the early sixties, an essay I sent $P M L A$ was forwarded for evaluation to my favorite graduate professors. Today were I to wrest some hours from my decanal duties to complete and submit an essay l've been brooding about, the paper could not be accepted before it had been read by at least nine scholars (a veritable supreme court), seven of whom (members of the Editorial Board) would discuss it at length. None of these readers would have any inkling of my identity; my evaluators might even decide that "this writer is not sufficiently familiar with $P M L A$ guidelines." So be it.

In his forthright retrospective essay in this issue John Fisher suggests that the recent move toward anonymous submissions was the result of "distrust." I would argue, to the contrary, that the Delegate Assembly's vote (ratified by the Executive Council) in favor of explicitly objective refereeing does not represent a fear of "authority" but is, rather, a measure of the association's hard-earned intellectual maturity. I am also convinced that, as a result of the rigorous evaluation processes initiated during William Schaefer's editorship, the essays accepted today are more learned than at any other time in the journal's long history. My opinions, of course, have subjective sources, though now, several months and one hundred miles from the editorial offices, I am, I hope, disinterested. 


\section{Notes on Contributors}

John Fisher also suggests, provocatively, that $P M L A$ should become a literary review, with essays by, say, Wayne Booth and Helen Vendler, poems by M. L. Rosenthal, and a chapter from a detective novel by Carolyn Heilbrun. During my years as editor it was, in fact, my privilege to publish Rosenthal-though not his poetry-as well as Booth and Vendler. As for our president, with all respect to her ratiocinative alter ego, Amanda Cross, I am delighted that she has contributed in her own voice a piece of moving prose to this centennial PMLA. I find others of these pieces moving, too, and regard all of them as remarkably informative. As befits a large, heterogeneous, and feisty association, the essays are remarkably varied. Some are more personal and hence more immediately accessible than others. Some are polemical, others learned, and at least one makes me chuckle. They all, I think you will agree, represent, though in different ways, timely statements by some of the most gifted members of our profession.

These essays were commissioned during my tenure in office and I am grateful to have been brought out of retirement, as it were, to introduce them. I want to thank John H. Fisher, Phyllis Franklin, Geoffrey H. Hartman, Karl Kroeber, Paul Lauter, Robert G. Mead, Jr., and George Winchester Stone, Jr., for donating so much time and wisdom to this historic undertaking. In spite of the problems our profession faces, there are causes for hope, and certainly the intellectual vitality demonstrated in these papers represents something that is strong, healthy, and exciting. I cannot, in fact, remember any issue of our journal more likely than this one to delight, instruct, and provoke our thousands of readers. These essays will be quoted, praised, and perhaps even attacked for years to come. And that, of course, is as it should be.

JoEL CONARROE

\section{Notes on Contributors}

MaRY ANN CaWs is distinguished professor of French and comparative literature at Hunter College and the Graduate School of the City University of New York. In addition to translating and editing numerous works, she has written extensively on French poetry and poetics and on art and literature, including, most recently, The Eye in the Text (Princeton Univ. Press, 1981), A Metapoetics of the Passage (Univ. Press of New England, 1981), and Reading Frames in Modern Fiction (Princeton Univ. Press, 1984). The recipient of Fulbright, Guggenheim, and NEH fellowships and an honorary doctorate of humane letters, she is an officier in the Palmes Académiques and a past Phi Beta Kappa Visiting Scholar. She is the editor of Le Siècle Eclaté: Dada, Surréalisme et les Avant-Gardes and coeditor of Dada/Surrealism.

JoHN H. FISHER is John C. Hodges professor of English at the University of Tennessee, where he has taught since 1972. He has served the MLA in several capacities: as treasurer from 1952 to 1955 , as executive secretary and editor of PMLA from 1963 to 1971, and as president in 1974. He has served on the executive committee and as American vice-president for the International Federation for Modern Languages and Literatures (FILLM) and this summer will deliver a paper at the FILLM congress in Budapest. The president of the New Chaucer Society, he has written extensively on medieval literature; the University of Tennessee Press plans to publish his Anthology of Chancery English, 1417-1455 this spring. His next project is the Variorum edition of The Wife of Bath's Tale.

Phyllis Frankin, director of the MLA's English Programs and the Association of Departments of English, did her graduate work at the University of Miami, where she taught from 1969 to 1980. She has held Danforth and NEH fellowships and has served on the MLA's Commission on the Status of Women. Now editor of the ADE Bulletin and coeditor of Profession, she is writing a book on the history of English studies in higher education.

GEOFFREY H. HARTMAN is chairman of the department of comparative literature at Yale. He is also director of the School of Criticism and Theory and a trustee of the English Institute, for which he has edited two volumes; from 1977 to 1980 he served on the MLA Executive Council. His numerous writings include The Unmediated Vision (Yale Univ. Press, 1954), Wordsworth's Poetry (Yale Univ. Press, 1964), Beyond Formalism: Critical Essays (Yale Univ. Press, 1970), and Criticism in the Wilderness: The Study of Literature Today (Yale Univ. Press, 1980). He has received the Christian Gauss Prize (for Wordsworth's Poetry), and his undergraduate alma mater, Queens College of the City University of New York, named him Alumnus of the Year in 1970. His current work is on the history of poetry and the history of criticism.

Carolyn G. Heilbrun, current president of the association, has taught at Columbia University 